in Marlène Benquet et Théor Bourgeron (dir.), Accumulating Capital Today. Contemporary Strategies of Profit and Dispossessive Policies, Londres, Routledge, 2021, pp. 224-234 - VERSION PROVISOIRE

\title{
15 Why do women accumulate less wealth than men?
}

Céline Bessière and Sibylle Gollac

\begin{abstract}
In contemporary capitalism, inequality of wealth is increasing. Some upper-class families appropriate economic capital and pass it on to their children, while others are permanently deprived of it. At the same time, while women have largely entered the labor market and the gender pay gap is on the political agenda in all Western countries, the gender wealth gap is not closing, quite the opposite. In this chapter we explore family wealth arrangements in France. Estate planning and marital breakdowns are two moments when families and legal professionals strive to preserve real estate and businesses, or to minimize taxes. For this purpose, they produce inventories, estimations and distributions of assets which end up disadvantaging women, even though shares may appear to be formally equal. Reversed accounting is a common logic of practice, in which the result comes first and computation only after, as a means to legitimize the sharing that has been (forcefully) agreed on. Thus, it is not only the wealth of the upper class that is underestimated, but more particularly men's wealth. Those mechanisms contribute to impoverish women. We conclude that class society reproduces itself thanks to the male appropriation of capital.
\end{abstract}

Consider two women. The first one is named Ingrid. Her family name, Levavasseur, is fairly common in Normandy. It means the vassal of a lord who is himself a vassal. Ingrid Levavasseur is born in 1987 in a rural area, close to the lower Seine Valley. With her three brothers and sisters, she is raised by their mother, a former cleaning woman who becomes a special needs caregiver. Their violent and alcoholic father, frequently taken charge of by the Salvation Army, is mostly out of the picture. At 16, Ingrid leaves her mother's home without graduating high school. She strings together a series of minor service jobs, waitress, cashier, and telephone operator, and then gets married. Two kids are born. A year after the birth of her second child, Ingrid and her husband divorce. She is just 24 years old. While working as a firefighter at night, she studies to become a nursing assistant. She gives up dreaming of becoming a nurse because she cannot afford the education and training. In 2018, she makes 1,250 euros a month, supplemented with a 95-euro housing credit and 200 euros in alimony for her two children aged 8 and 13 years, for whom she has sole custody. She lives in a small rented house in the town of 
in Marlène Benquet et Théor Bourgeron (dir.), Accumulating Capital Today. Contemporary Strategies of Profit and Dispossessive Policies, Londres, Routledge, 2021, pp. 224-234 - VERSION PROVISOIRE

Pont-de-l'Arche, and she puts her children in day care while she works in Rouen, 20 kilometers away. Family vacation consists of three days a year at a campground near Mont-St-Michel. She has trouble buying her kids new sneakers, and keeping the fridge stocked all month. Ingrid long ago stopped spending money on herself: no haircuts, no sports, never dining out. At any rate, when would she find the time? Every other weekend when the kids are with their father? In the autumn of 2018, Ingrid Levavasseur becomes a national figure as a part of the French Gilets jaunes movement ${ }^{\underline{1}}$. With her straight red hair and Botticellian face, she is an immediately recognizable figure in news reports; a face for decades-old statistics that describes the poverty of women running single parent households. In 2019 she announces she is creating a support center providing lodging, child-care, and activities for women raising their children alone.

The Gilets jaunes movement places many anonymous members of the working class in a spotlight of media attention they have not known before. The presence of numerous women is remarkable, whether camping out at highway toll booths, or leading demonstrations. ${ }^{2}$ A number of them raise their children alone, and find it hard to make ends meet to the end of the month. For news cameras and microphones, they speak of overdue alimony payments and long administrative waits within social services systems to receive limited public assistance. They tell how they are constantly juggling bills, putting their children's needs before their own. Women in couples voice their concern of paying the bills. Some women speak about unemployment, parttime jobs, and having to take on as many work hours as possible. Others have given up on salary work to become self-employed; this does not provide a better income. Finally, there are retired women, often widows, who receive a meager pension. Among the poor, money problems are women's problems (Desmond, 2016). 
in Marlène Benquet et Théor Bourgeron (dir.), Accumulating Capital Today. Contemporary Strategies of Profit and Dispossessive Policies, Londres, Routledge, 2021, pp. 224-234 - VERSION PROVISOIRE

The second woman is named MacKenzie. She is born in San Francisco in 1970 to a well-off family with a financial planner father and a full-time wife and mother. She gets a degree in English from Princeton, where she attends Toni Morrison's seminars, in the hope of becoming a novelist. In the early 1990s she works at the investment firm of D.E. Shaw\&Co in New York, a job that pays the bills and leaves her time to write. She meets her future husband there, Jeff Bezos; a computer scientist by trade and fellow Princeton graduate, who has become a senior vice president at the hedge fund by the time they meet. Jeff is the one who hired MacKenzie; he occupies the office next to hers. In 1993, they get married. She is 23 years old. He is 30 . The next year, they move to the west coast, to a little rented house in the suburbs of Seattle. During their drive across the United States, with MacKenzie at the wheel and Jeff in the passenger seat, they develop a business plan for a new company that would sell books over the internet. The business that is created the next year later takes the name of Amazon.

In the beginning, MacKenzie is fully involved with the business. She does the bookkeeping, participates in hirings and strategy sessions, and dives into the basic work of sending packages out via UPS: "I was there when he wrote the business plan, and I worked with him and many others in the converted garage, the basement warehouse closet, the barbecue-scented offices, the Christmas-rush distribution centers, and the door-desk filled conference rooms in the early years of Amazon's history", she declares in a later interview when the business has become the world's largest online retailer.

In 1999, the couple's first child is born; to be followed by three others. MacKenzie and Jeff move into a 10-million-dollar house. MacKenzie starts working less for the company. She also sets aside her ambitions of becoming a novelist to take care of the four children. (Later, she explains that she could have hired nannies, but that she preferred to look after the children 
in Marlène Benquet et Théor Bourgeron (dir.), Accumulating Capital Today. Contemporary Strategies of Profit and Dispossessive Policies, Londres, Routledge, 2021, pp. 224-234 - VERSION PROVISOIRE

herself, even home schooling them during certain periods). In 2005, her first novel is published, on which she has worked for over ten years. A second novel follows in 2013. It is critically wellreceived, but sales remain modest, around a couple of thousand copies. Book stores refuse to sell the novel because her husband's business has destroyed their own ${ }^{3}$.

On January 9, 2019, after 25 years of marriage, MacKenzie and Jeff Bezos announce their divorce in a joint tweet: "We want to make people aware of a development in our lives [...] we have decided to divorce and continue our shared lives as friends [...] We've had such a great life together as a married couple, and we also see wonderful futures ahead, as parents, friends, partners in ventures and projects, and as individuals pursuing ventures and adventures".

This message stages an amicable divorce settlement that is destined less for their friends than for financial markets, investors, and shareholders. The future of the world's largest private fortune is in play: an estate worth over 130 billion dollars that includes a large portion of Amazon's capital including $16 \%$ of its shares. In Washington State, where the couple lives and works, divorce laws stipulate that all assets acquired during the marriage must be divided into two equal parts. Hundreds of newspaper articles around the world expressed concern about the future of the Bezos fortune, a large portion of which consists of companies: Amazon, but also the aerospace company Blue Origin, or the daily newspaper The Washington Post. 8\% of Amazon risks falling into the hands of a woman, possibly leading to Jeff Bezos losing control of the company; a possibility that makes financial markets anxious ${ }^{4}$.

Three months later, the details of the divorce are made public by the couple, again on Twitter: "Grateful to have finished the process of dissolving my marriage with Jeff, with support from each other and everyone who reached out to us in kindness, and looking forward to next phase as co-parents and friends. Happy to be giving me all my interest in the Washington Post and Blue 
in Marlène Benquet et Théor Bourgeron (dir.), Accumulating Capital Today. Contemporary Strategies of Profit and Dispossessive Policies, Londres, Routledge, 2021, pp. 224-234 - VERSION PROVISOIRE

Origin and $75 \%$ of our Amazon stock plus voting control of my shares to support his continued contributions with the teams of these incredible companies", MacKenzie writes. Jeff Bezos thus remains the primary shareholder of Amazon stock and retains control. He is still today the richest man on Earth. Among the ultra-rich caring for capital is a man's prerogative (Herlin-Giret, 2019: p. 69).

\section{Wealth accumulation, class, and gender}

An ocean and billions of dollars separate the lives of Ingrid Levavasseur and MacKenzie Scott. The wealth of the former would likely include her car and some modest savings, probably no more than a couple thousand euros. MacKenzie Scott exited her marriage with 35 billion dollars. As Thomas Piketty's Capital in the Twenty-First Century has made clear to a larger public, wealth inequality is a central characteristic of contemporary capitalism (Piketty, 2014). Even more pronounced than income inequality, wealth inequality better describes the ever-widening chasm separating the worlds of MacKenzie Scott and Ingrid Levavasseur. According to the 2018 World Inequality Report, among the inhabitants of Europe, the United States, and China, the top $1 \%$ control a third of the world's wealth; and the top $10 \%$ dispose of $70 \%$ of the world's wealth; while the poorest half of this population only possesses $2 \%$ of it. Accumulation of economic capital shapes the contemporary social class structures more than ever before. Marx defined the relationship between the social classes on the basis of the ownership of productive capital as opposed to the ownership of labor power alone. In the 20th century, in Western countries, the relations of exploitation were transformed by the generalization of the wage system, which at first was despised, then has been progressively associated with social protections (Castel, 2017 [1995]). In the wage system, social hierarchy 
in Marlène Benquet et Théor Bourgeron (dir.), Accumulating Capital Today. Contemporary Strategies of Profit and Dispossessive Policies, Londres, Routledge, 2021, pp. 224-234 - VERSION PROVISOIRE

largely derives from educational qualifications. It was thus between work and school that sociologists examined the construction of class relations.

However, at the beginning of the 21 st century, differences in living conditions and social status are increasingly linked to the family transmission of economic capital. There are two different ways of accumulating wealth: by putting money aside or by inheriting it. While during the 1950s and 1960s inheritances represented less than half of the private wealth held by individuals in France, this proportion has only increased, and represented $60 \%$ of wealth in 2010 (Alvaredo, Garbinti, Piketty, 2017). We are certainly a long way from the 1910s when inherited wealth represented $80 \%$ of total private wealth, but if current economic and demographic trends continue, the inherited portion of wealth will keep on increasing during the 21 st century. Today, family economic capital is more and more crucial to obtain housing, especially in a context where property is both widespread and socially distinctive. Furthermore, while a society based on salary work slowly fades away, family economic support can prove indispensable for starting a business, maintaining its economic activities, gaining access to credit, or for obtaining added revenue from the family assets. The accumulation of academic capital also depends more and more on the mobilization of family savings (Zaloom, 2019). The material conditions of life influence children's success at school from a very young age (Lahire, 2019).

In other words, Ingrid Levavasseur's precarious economic situation will likely affect her children's academic future and reduce their chances for social success. Even if her daughter and son excel in school, and find some employment with a good salary, it will still take them quite some time to start accumulating their own assets. At the same time, MacKenzie Scott's children will likely have ready access to the best schools and universities. Her three sons and her daughter 
in Marlène Benquet et Théor Bourgeron (dir.), Accumulating Capital Today. Contemporary Strategies of Profit and Dispossessive Policies, Londres, Routledge, 2021, pp. 224-234 - VERSION PROVISOIRE

will probably never need to borrow money to buy a home, to start a business, or to partner in a sound investment and this, even if they have trouble proving their worth in college.

In our book The Gender of Capital we approach the institution of family from a materialistic point of view breaking with the dominant theory of a modern relationship-based family, free of financial stakes. In our perspective, the family should be designed as a unit that produces, circulates, controls and evaluates assets (Bessière and Gollac, 2020). We reconnect with feminist theory born in the wake of the women's liberation movement and inspired by Marxism: materialist feminism. Christine Delphy and Diana Leonard have shown that family wealth in the 1960s was accumulated and transferred to the next generation based on the exploitation of married women's unpaid labor (Delphy and Leonard, 1992). Is this still the case today, in contemporary France, a country that celebrates gender equality?

Obviously, Ingrid Levavasseur and MacKenzie Bezos are worlds apart. Nonetheless, there are common points worth noticing between the lives of these two women. When they were part of couples, each found their proper place in a household economy by taking care of the children. Both women made professional sacrifices, putting off or giving up on projects that had been near to their hearts. Their professional lives were parceled out into a succession of smaller tasks, rather than integrated into a linear career. Both women faced also a challenging divorce surrounded by legal professionals who promoted specific kinds of legal advice. At the very least Ingrid would have had a lawyer, MacKenzie, several. For these women divorce resulted in their relative impoverishment with respect to their former situation. The 100 euros per child per month that Ingrid receives as alimony does not even cover half of the costs for their support and education. Who could possibly house, feed, clothe, care for, and cover all of the other costs of raising a child today in France for 100 euros per month? As for MacKenzie Scott, half-owner of 
in Marlène Benquet et Théor Bourgeron (dir.), Accumulating Capital Today. Contemporary Strategies of Profit and Dispossessive Policies, Londres, Routledge, 2021, pp. 224-234 - VERSION PROVISOIRE

a colossal conjugal fortune at the time of her divorce, she had to content herself with a much smaller portion of that fortune, since the majority went instead to her ex-husband.

On both the highest and lowest rungs of the social ladder, these two women's situations raise fundamental questions. Why is it that in the working class, women are at the forefront of dealing with money problems, while higher up the social ladder, economic power is monopolized by men? Historically, legal discrimination has hindered women from accumulating wealth almost everywhere in the world. In the 19th and 20th centuries, Western societies seemed to have achieved legal gender equality concerning worker's rights, family rights, and property rights. Yet despite these formally equal rights, men still continue to accumulate far more wealth than women.

\section{Women's work, men's salaries}

For those who think that this economic inequality is explained by the fact that women earn less than men because they work less than men, it is important to remember that women have always worked as much as men, if not more (Kessler-Harris, 1981).

One obvious characteristic of women's work for more than two centuries in a number of economic sectors (starting with agriculture, but also including crafts, commerce, and industry) is its invisibility, in the absence of judicial or financial recognition. Housework, primarily accomplished in family settings by women, is the archetype of unpaid work that never quite gets recognized as such (Dalla Costa and James, 1972; Federici, 2012). Domestic production is not counted in the large statistical aggregates that measure production from the perspective of national accounting. National income only includes activities that produce goods and services for commercial exchange, or for those furnished as part of public administration (Waring, 1988). A 
in Marlène Benquet et Théor Bourgeron (dir.), Accumulating Capital Today. Contemporary Strategies of Profit and Dispossessive Policies, Londres, Routledge, 2021, pp. 224-234 - VERSION PROVISOIRE

preschool Assistant Teacher who takes care of a child contributes to the national income, while a mother who does the same work does not. If household production were to be taken into account, the gross national product (GNP) in 2010 would have been 33\% larger in France, 63\% larger in the UK, and 43\% larger in Germany; and in 2014 in the United States 23\% larger (Bridgman, 2016; Poissonnier and Roy, 2017).

This unpaid and invisible household production is financed largely by women. In France, in 2010, among couples with infants, women worked on average 54 hours per week: 34 hours of unpaid housework and 20 hours of professional activity. Within the same households, men worked only 51 hours, 3 hours less per week. Men devoted on average 18 hours per week to unpaid housework, and 33 hours to professional activities (Source: the French Time Use Survey). In the end, women worked a bit more, but were paid much less.

These figures established by the French national institute for statistical and economic studies (INSEE) from men's and women's work data, do not account for the fragmentation of women's work, both domestic and professional, which is permanently interrupted because women must always make themselves available to others (Oakley, 1985[1974]). Women always carry with them a domestic mental load, even during paid work ${ }^{\underline{5}}$. Women are the first people contacted by schools and day care centers when children are sick. Women often multitask (doing housework while watching the kids) and must interrupt what they are doing at any moment when the need arises. To the contrary, men's work, whether professional or household (handiwork, repairs, gardening, or maybe cooking) is more clearly delineated in time and space.

Salary inequality thus summarizes a wide range of other inequalities that accumulate in families and in the job market, both at the top and at the bottom of the work hierarchy. Women are concentrated in less well-paid sectors: educational, care giving, and personal assistance 
in Marlène Benquet et Théor Bourgeron (dir.), Accumulating Capital Today. Contemporary Strategies of Profit and Dispossessive Policies, Londres, Routledge, 2021, pp. 224-234 - VERSION PROVISOIRE

professions notably (Ingrid Levavasseur's employment as a care assistant is typical). Because of their family duties, women are often employed in part-time jobs and their careers run on a slower track. Furthermore, glass ceilings prevent them from reaching the best-paying positions (Gustafsson and Meulders, 2000). These factors help to explain why women, in France like elsewhere in the world, earn on average about one quarter less than men do. But even ceteris paribus (for the same age, seniority, job sector, position, years of employment, etc.) the job market still discriminates against women, providing them with a salary $10.5 \%$ lower than their male counterparts (Silvera, 2014). These persistent inequalities are intertwined with other inequalities that play out in private family life. In France, according to the French national institute for statistical and economic studies, the income of women living in a couple is, on average, 42\% less than their partner. In 2011 she earned 16,700 euros while he earned 29,000 euros. This gap in incomes is only $9 \%$ between women and men who live alone. Different-sex marital relations endorse existing economic inequalities and then firmly fix them in place. Today, Western societies would appear to have addressed questions of unequal salaries between men and women with laws focused on professional equality. Alas, even if women were paid with equal salaries for equal work, this still would not resolve everything. There exists an economic inequality between women and men that does not show up on most political and statistical radars, that, nonetheless, structures and summarizes the socioeconomic destinies of individuals, and that is transferred from one generation to the next.

\section{From unequal pay to unequal wealth}

To measure that inequality, one must become interested not only in income but also in wealth. At an individual level, what is meant by the terms assets, wealth, and capital (terms that are easily 
in Marlène Benquet et Théor Bourgeron (dir.), Accumulating Capital Today. Contemporary Strategies of Profit and Dispossessive Policies, Londres, Routledge, 2021, pp. 224-234 - VERSION PROVISOIRE

interchanged in contemporary economic literature) is the total value that a person possesses at a given moment. In practice this can be land, real estate, financial assets, or businesses. Wealth consists of economic assets whose acquisition permits the conservation (or accumulation) of their value, and whose final fruition (through sale) can guarantee future cash flows ${ }^{6}$. Individual wealth inequality stems in part from income inequality, but it also depends on the way wealth is transmitted within families.

The investigation of wealth inequality between men and women recently has received more attention. The few statistical analyses currently available show that, throughout the world today, men possess more assets than women (Sierminska, 2017; Chang, 2010; Deere and Doss, 2006). This should not be surprising in itself, given the income inequality between the sexes. Yet, in France, according to recent statistical data from the French Household Wealth Survey, the gender wealth gap is widening steadily: from 9\% in 1998 to 16\% in 2015 (Frémeaux and Leturcq, 2020). The same study also shows that men retain much more capital than women, whatever the form: housing, land, financial, or professional capital. In 2015, the average wealth gap between women and men was estimated at 24,000 euros, covering a wide variety of situations: from modest differences between working-class men and women, as neither partner accumulates much wealth, to immense gender gaps among the wealthiest classes.

\section{Investigating the making of gender wealth inequality in the family}

The gender wealth gap does not emerge from Wall Street, but in the daily struggles of family

life. This inequality is produced by the unspoken practices of men and women when they act as spouses and partners, fathers and mothers, daughters and sons, brothers and sisters. The inequality takes on different forms based on class: based on whether wealth consists of debts or 
in Marlène Benquet et Théor Bourgeron (dir.), Accumulating Capital Today. Contemporary Strategies of Profit and Dispossessive Policies, Londres, Routledge, 2021, pp. 224-234 - VERSION PROVISOIRE

goods, on whether it includes several thousand euros in a savings account passbook, a suburban bungalow, a Parisian apartment, a family country home, a timeshare, stocks in a company, or works of art. To make the inequality visible, one must look at the family in a different way. One should consider the family as a fully integrated economic institution that produces wealth, but also organizes wealth's circulation, control, and evaluation under what we call family economic arrangements.

As sociologists, we have been studying for more than 20 years these ordinary economic arrangements of French families from the most modest to the wealthiest backgrounds. Barely visible, these arrangements can take many forms: small hand-outs, free lodging, security deposits, interest-free loans, contributions, inheritances, references, college financing, home health care for an aging parent, moving in to help out in an emergency, watching children, paying alimony, and so forth. Family economic arrangements are considered private, and the public discussion of their economic aspects is often frowned on. To study this subject, multiple methodologies and sources of input are necessary.

First, we carried out family monographs based on repeated and intersectional observations and interviews with groups of kin. These relatives invited us to participate in their daily lives, and in their more exceptional family moments: marriage ceremonies, funerals, celebrations. We stayed in their homes. Some of them entrusted us with their most intimate archives: notarized certificates, civil registrations, correspondence, and photographs. By using this method from 1997 to 2005, Céline Bessière studied how family businesses were transferred in the Cognacproducing area. Similarly, Sibylle Gollac investigated real estate property strategies in families from different social backgrounds, several of whom she followed for more than 15 years. 
in Marlène Benquet et Théor Bourgeron (dir.), Accumulating Capital Today. Contemporary Strategies of Profit and Dispossessive Policies, Londres, Routledge, 2021, pp. 224-234 - VERSION PROVISOIRE

In completing these family monographs, we described family economic transfers in some detail.

We noted that some brothers and sisters recalled quite differently the various stages of estate planning: not counting the same assets, or accounting for them differently, thus proposing extremely divergent conceptions of what a fair inheritance might mean. But family wealth arrangements are about more than money and property. As Viviana Zelizer has noted, these are intimate transactions, that is, a mixing of economic activity with intimate social relations involving emotions, moral obligations, values, principles of justice, and issues about reputations that are all inscribed in a long-term narrative of interpersonal relations (Zelizer, 2005).On the whole, men and women do not occupy the same place in this process: neither acts in the same way or has the same aspirations; and their loved ones do not expect the same things from both of them.

Because family monographs cannot be used to research a large number of people, and because they make it difficult to compare different social classes, we combined them with statistics, particularly data arising from the French Household Wealth Survey. To dig deeper into an analysis of the gender wealth gap, we also implemented field studies to describe two extraordinary moments which clarify and formalize family wealth arrangements: marital separation and estate planning.

Splitting up. Inheriting: two moments that are strictly legally codified. These are matter of family, fiscal, and civil law. Based on social class, relatives may have to meet with legal professionals who accompany them in a more or less diligent fashion throughout this confrontation with law. Our research thus brought us into other locations: the offices of family practice lawyers and notaries, and civil family courts. Though we separately conducted studies that led to the family monographs, we worked together investigating notaries. As for materials 
in Marlène Benquet et Théor Bourgeron (dir.), Accumulating Capital Today. Contemporary Strategies of Profit and Dispossessive Policies, Londres, Routledge, 2021, pp. 224-234 - VERSION PROVISOIRE

related to family courts and lawyers, these were collected as a part of a larger collective study begun in $2008^{7}$.

\section{The gender of capital}

Certain social classes monopolize wealth and work to preserve it among themselves from one generation to the next, while other social classes are persistently deprived of it. At the same time, women accumulate less wealth than men. Class inequality and gender inequality are intertwined. Studies led in other national contexts than France, particularly in the United States, have also documented a racial dimension to wealth inequality. Age and generation also constitute factors of inequality. Our work thus has an intersectional perspective that articulates without prioritizing several relations of power and domination. In exploring family wealth arrangements, we are studying the concrete places where these different dynamics of inequality inseparably play out. We show that not only do the wealthy have more assets to pass on from one generation to the next, but also, they pass on these assets in a more efficient way, notably thanks to underestimation and tax optimization techniques. These techniques are all the more effectively implemented by legal professionals because of a class affinity between them and their clients. This affinity is based both on the size and nature of the economic capital held, but also on the possession of a certain cultural capital.

We show that these processes which ensure that wealth remains in the hands of certain families are also gendered. As families and legal professionals strive to preserve real estate and businesses, or to minimize taxes, they produce inventories, estimations and distributions of assets which end up disadvantaging women, even though shares may appear to be formally equal. Reversed accounting is a common logic of practice, in which the result comes first and 
in Marlène Benquet et Théor Bourgeron (dir.), Accumulating Capital Today. Contemporary Strategies of Profit and Dispossessive Policies, Londres, Routledge, 2021, pp. 224-234 - VERSION PROVISOIRE

computation only after, as a means to legitimize the sharing that has been (forcefully) agreed on (Bessière, 2019). Thus, it is not only the wealth of the upper class that is underestimated but more particularly men's wealth.

We conclude that class society reproduces itself thanks to the male appropriation of capital. It is not only that gender inequality is found in all social backgrounds: class relations and male domination are inseparable. The reproduction of the gender order is played out in the processes of conservation and transmission of wealth within the different classes. Conversely, the reproduction of the class order is based on processes of male enrichment and female impoverishment. At a time when family wealth increasingly determines the social status of individuals, gender inequality will not be defeated without tackling class inequality, and class society will not be abolished without equalizing the gender order.

\footnotetext{
Notes

${ }^{1}$ Portrait of Ingrid Levavasseur based on several interviews and press articles, notably, Clier A., Qui est Ingrid Levavasseur, figure nationale des Gilets jaunes originaire de Pont-de-l'Arche?, Paris-Normandie, 12 January 2019; Ballet V., Ingrid Levavasseur, rond-point en suspension, Libération, 1 April 2019.

${ }^{2}$ Lombard-Latune M.-A. and Ducros C., Ces femmes Gilets jaunes qui ont investi les ronds-points, Le Figaro, 13 December 2018; Lucas E., Des mères isolées ont porté le gilet jaune, La Croix, 7 March 2019; Agence France Presse, Des centaines de femmes Gilets jaunes manifestent dans plusieurs villes de France, Le Monde, 6 January 2019.

${ }^{3}$ Portrait of MacKenzie Bezos based on several interviews and press articles, notably: Johnson R., MacKenzie Bezos: writer, mother of four, and high-profile wife, Vogue, 20 February 2013; Bromwich J. E. and Alter A., Who is MacKenzie Bezos?, New York Times, 12 January 2019.

${ }^{4}$ Holson L. M., Jeff Bezos of Amazon and MacKenzie Bezos plan to divorce, New York Times, 9 January 2019; Weise K., Jeff Bezos, Amazon CEO, and MacKenzie Bezos finalize divorce details, New York Times, 4 April 2019.
} 
in Marlène Benquet et Théor Bourgeron (dir.), Accumulating Capital Today. Contemporary Strategies of Profit and Dispossessive Policies, Londres, Routledge, 2021, pp. 224-234 - VERSION PROVISOIRE

5. The mental load describes a psychological weight that crops up during both domestic and professional tasks. One must not simply complete the task, but organize when and how to complete it. For instance, while still at work thinking, a mother thinks of what to make for dinner, what groceries will be needed, and when to find the time to cook between picking the kids up at school, taking them to extracurricular activities, and helping them with their homework.

${ }^{6}$. We are working here off of Thomas Piketty's definition in Capital in the Twenty-First Century. Contrary to a classic marxist definition, Piketty does not limit the notion of capital to those elements of wealth used directly in the process of production or for which the owner expects a return. He includes in his definition of capital land and natural resources on which it is possible to exercise property rights, wealth as a value reserve such as gold, or rights to possession and use such as an apartment. His definition of capital is thus a synonym for contemporary economics definitions for wealth and assets.

7. A description of the research team and its activity can be found here: http://justines.cnrs.fr

\section{References}

Alvaredo, F., Garbinti, B. and Piketty T. (2017). On the Share of Inheritance in Aggregate Wealth: Europe and the USA, 1900-2010, Economica, 84, 237-260.

Bessière, C. (2019). Reversed Accounting: Legal Professionals, Families and the Gender Wealth Gap in France. Socio-Economic Review (DOI: 10.1093/ser/mwz036)

Bessière, C. and Gollac S. (2020). Le Genre du Capital. Comment la Famille Reproduit les Inégalités. Paris: La Découverte.

Bridgman, B. (2016). Accounting for Household Production in the National Accounts: An Update, 1965-2014, Survey of Current Business, 96, 2, 1-5.

Castel, R. (2017 [1995]). From Manual Workers to Wage Laborers: Transformation of the Social Question. New York: Routledge.

Chang, M. L. (2010). Shortchanged: Why Women Have Less Wealth and What Can Be Done About It. New York: Oxford University Press.

Dalla Costa, M. and James, S. (1972). The Power of Women and the Subversion of the Community. Bristol: Falling Wall Press.

Deere, C. D. and Doss, C. (2006). The Gender Asset Gap: What Do We Know and Why Does It Matter?, Feminist Economics, 12, 1-50.

Delphy, C. and Leonard, D. (1992). Familiar Exploitation. A New Analysis of Marriage in Contemporary Western Societies. Cambridge: Polity Press. 
in Marlène Benquet et Théor Bourgeron (dir.), Accumulating Capital Today. Contemporary Strategies of Profit and Dispossessive Policies, Londres, Routledge, 2021, pp. 224-234 - VERSION PROVISOIRE

Desmond, M. (2016). Evicted. Poverty and Profit in the American City. New York: Crown Publishing.

Federici, S. (2012). Revolution at Point Zero: Housework, Reproduction, and Feminist Struggle. Brooklyn, Oakland: Common Notions/PM Press.

Frémeaux, N. and Leturcq, M. (2020). Inequalities and the Individualization of Wealth, Journal of Public Economics, 184, 104-145.

Gustafsson, S. and Meulders D., eds. (2000). Gender and the Labor Market: Econometric Evidence on Obstacles in Achieving Gender Equality. London: Mac Millan.

Herlin-Giret, C. (2019). Rester Riche. Enquête sur les Gestionnaires de Fortune et Leurs Clients. Lormont: Le Bord de l'eau.

Kessler-Harris, A. (1981). Women Have Always Worked: A Historical Review. New York: The Feminist Press.

Lahire, B., ed. (2019). Enfances de Classe. De l'Inégalité Parmi les Enfants. Paris: Le Seuil.

Oakley, A. (1985 [1974]). The Sociology of Housework. Oxford: Basil Blackwell.

Piketty, T. (2014). Capital in the Twenty-First Century. Cambridge, MA: Harvard University Press.

Poissonnier, A. and Roy, D. (2017). Household Satellite Account for France. Methodological Issues on the Assessment of Domestic Production, The Review of Income and Wealth, 63, 2, $353-377$

Silvera, R. (2014). Un Quart en Moins. Des Femmes se Battent et Obtiennent l'Egalité des Salaires. Paris: La Découverte.

Sierminska, E. (2017). Wealth and Gender in Europe. Report for the European Commission. Luxembourg: Publication Office of the European Union.

Waring, M. (1988). If Women Counted: a New Feminist Economics. San Francisco, CA: Harper \& Row.

Zaloom, C. (2019). Indebted. How Families Make College Work at Any Cost. Princeton, NJ: Princeton University Press.

Zelizer, V. (2005). The Purchase of Intimacy. Princeton, NJ: Princeton University Press. 